\title{
BENTUK LENGKUNG PADA PESANGGRAHAN- PESANGGRAHAN KESULTANAN YOGYAKARTA (Tinjauan Arsitektur berdasarkan bentuk, fungsi, konstruksi dan simbol)
}

\author{
Oleh: Enny Ratna Dewi
}

Suatu hal yang umum dijumpai pada kota-kota Islam di Iñdonesia adalah bahwa di samping bangunan kraton, terdapat alun-alun, masjid Agung, serta pasar. Bangunan kraton yang merupakan pusat pemerintahan dilengkapi pula dengan benteng atau tembok keliling, masjid, dan taman. Taman dapat didirikan di dalam atau di luar, lingkungan kraton. Demikian pula halnya dengan taman-taman yang terdapat di Yogyakarta. Taman yang didirikan di dalam lingkungan kraton Yogyakarta adalah Tamansari, sedangkan yang didirikan di luar lingkungan kraton antara lain adalah Nyarjakusuma. Rejowinangun, Wanacatur (Semak), serta Gua Siluman.

Taman-taman di Yogyakarta erat berhubungan dengan masa awal kesultanan Yogyakarta. Sultan-sultan Yogyakarta, khususnya sultan $\mathrm{Ha}$ mengku Buwana I dan Hamengku Buwana II terkenal gemar mendirikan taman-taman. Salah satu taman hasil karya Sultan Hamengku Buwana I yang dikenal hingga saat ini adalah Tamansari. Sedangkan tamantaman yang dibuat oleh Sultan Hamengku Buwana II disebutkan dalam Serat Rerenggan Kraton, meliputi Jawinangun, Ngarjakusuma, Purwareja, Wanacatur, Cendanasari, Pengawatreja, Tanjungtirta, Sanasewu, 
Sanapakis tlaga ji Ngambar Ketawang, Toya tumumpang Kanigara serta Madya Ketawang dan Kraapyak. ${ }^{1}$ Dari sekian banyak yang disebutkan di dalam Serat tersebut hanya beberapa taman saja yang secara fisik dapat dikenali, yaitu Jawinangun, Rejakusuma, Cendanasari, Wanacatur, serta Gua Siluman.

Di luar Indonesia misalnya di Spanyol, Iran, Asia Tengah, dan India terdapat kecenderungan penciptaan taman (garden) untuk meningkatkan kenyamanan pada lokasi-lokasi hunian manusia. ${ }^{2}$ Kecenderungan tersebut merupakan jawaban dari kondisi lingkungan alam yang pada umumnya kurang memberikan kenyamanan hidup bagi masyarakat banyak. Gagasan semacam ini diwujudkan dalam bentuk taman yang pada umumnya memiliki unsur air dan tumbuh-tumbuhan. Di Cina pendirian taman-taman terutama lebih ditekankan pada kepentingan pribadi penguasa pada masa itu. ${ }^{3}$ Sebuah taman dibuat sedemikian indah sehingga benar-benar dianggap sebagai replika dari surga. ${ }^{4}$ Segala unsur yang terkandung pada taman merupakan simbol-simbol dari alam atas. Taman-taman tersebut berfungsi sebagai tempat beristirahat serta tempat pertahanan. ${ }^{5}$ Selain itu terdapat taman yang berfungsi untuk tempat berburu. Karena fungsi-fungsi tersebut maka taman-taman di Cina mempunyai unsur-unsur air, tumbuhan. serta unsur bangunan.

Taman-taman di Indonesia dijumpai di daerah Aceh yang dikenal dengan nama Taman Ghairah Aceh, di Cirebon dengan nama Taman Air Sunyaragi, serta di Yogyakarta. Taman yang berada di Yogyakarta disebut sebagai pesanggrahan. Arti pesanggrahan di dalam kamus Kawi-Indonesia adalah tempat berkumpul. tempat jamuan, tempat beristirahat. ${ }^{6}$

1. Serat Rerenggan Kraton, Alih Aksara oleh Aryono (Jakarta: Proyek Penerbitan Buku Sastra Indonesia dan Daerah. 1981). hlm. 131.

2. Richard Etting Hausen, "The Man Made Setting". The World Of Islam (London Thames and Huson). hlm. 70-71.

3. Yang Hongxun, The Classical Gardens Of China (New York: Van Nostrand Reihold Company, 1982), hlm. 49.

4. Ibid, hlm. 13.

5. Ibid. hlm. 85 .

6. S. Wojowasito, Kamus Kawi-Indonesia (Malang : , 1977) hlm. 236. 
Dari arti kata tersebut tampak bahwa fungsi pesanggrahan adalah sebagai tempat beristirahat. Selain sebagai tempat beristirahat, di beberapa pesanggrahan di Yogyakarta didapatkan suatu petunjuk mengenai fungsi lain, yaitu sebagai tempat/pertahanan,| menyepi, serta berburu. Denys Lombart berpendapat bahwa pendirian suatu pesanggrahan merupakan indikasi bahwa pada masa itu sudah ada kekhawatiran kekurangan binatang buruan. ${ }^{7}$ Pendirian pesanggrahan di sini dimaksudkan antara lain untuk mensuakakan binatang buruan. Dalam hal ini tentunya tindakan tersebut cenderung dilakukan untuk kepentingan pribadi.

Pada kompleks pesanggrahan biasanya dijumpai unsur air yang diwujudkan dalam bentuk kolam ataupun danau buatan, tumbuh-tumbuhan, bangunan, serta tembok keliling. Masing-masing unsur tersebut dirancang untuk menunjang fungsi pesanggrahan. Dalam tulisan ini akan dicoba meninjau sekilas tentang salah satu unsur bangunan yang terdapat di kompleks pesanggrahan-pesanggrahan Tamansari, Rejowinangun, serta Gua Siluman. Unsur bangunan yang dipilih adalah bangunan yang memiliki langit-langit berbentuk lengkung serta ambang atas jendela dan pintu berbentuk lengkung. Bagian-bagian tersebut dijumpai di pesanggrahan Tamansari, Rejakusuma, serta Gua Siluman. Selanjutnya dari pembicaraan tersebut akan dicari hubungan antara bentuk lengkung dengan fungsi pesanggrahan serta faktor pengaruh lainnya yang menimbulkan terwujudnya bentuk lengkung.

Salah satu gejala yang dijumpai pada pesanggrahan-pesanggrahan di Yogyakarta adalah bentuk lengkung. Bentuk lengkung tersebut digunakan pada 1) langit-langit suatu bangunan; 2) ambang jendela dan pintu.

\section{Bentuk lengkung pada langit-langit}

Bentuk lengkung pada langit-langit dijumpai pada bangunan di pesanggrahan Tamansari, Rejawinangun, dan Gua Siluman. Di Tamansari

7. Denys Lombard, "Pandangan Orang jawa Terhadap hutan", Citra Masyarakat Indonesia (Jakarta : Sinar Harapan, 1983), hlm. 246. 
bangunan yang memiliki langit-langit lengkung antara lain berupa bangunan bawah tanah atau air di sebelah barat Pulo Cemeti, berupa lorong yang membujur ke utara. Lubang angin berada di bagian atap yang berbentuk tajug sebanyak 5 (lima) buah. Untuk memasuki lorong ini disediakan pintu-pintu. Selain itu di Tamansari dijumpai pula bangunan lorong yang melingkar temu gelang yang terletak pada Sumur Gumuling serta lorong bawah tanah yang menghubungkan antara Sumur Gumuling dengan Pulo Kenanga. Lorong yang melingkar temu gelang merupakan dua buah bangunan yang terletak di bawah dan di atas tanah. ${ }^{8}$ Pada lorong bagian atas didapatkan ceruk yang menyerupai mihrab.

Di pesanggrahan Rejowinangun bangunan yang berlangit-langit lengkung terdapat di permukaan tanah, yang merupakan bagian atas dari suatu bangunan yang bertingkat. Pada bangunan ini dijumpai ceruk yang mirip sebuah mihrab dari suatu masjid. Sedangkan di Gua Siluman bangunan berlangit-langit lengkung merupakan bangunan bawah tanah. Bangunan ini berupa sebuah lorong yang membujur arah utara selatan. Lubang angin bangunan ini terletak di bagian atap yang berbentuk empat persegi. Untuk masuk ke ruangan bangunan ini disediakan pintu yang terletak di ujung utara. Bangunan tersebut saat ini terletak di bawah jalan Gedong Kuning menuju ke Berbah.

\section{Bentuk lengkung pada ambang atas pintu dan jendela}

Hampir semua pintu atau jendela yang terdapat pada pesanggrahan Tamansari, Rejowinangun, serta Güa Siluman memakai bentuk lengkung. Pintu atau jendela yang tidak berambang lengkung dibuat berambang datar, tetapi di bagian atas ambang tersebut biasanya didapatkan tonjolan yang berbentuk lengkung. Misalnya yang terdapat pada beberapa pintu atau jendela pada pesanggrahan Rejowinangun, pintu masuk lorong Gua Siluman, serta pintu masuk lorong bawah tanah sisi selatan.

8. Tashadi (Ed), Mengenal Sekitar Bangunan Pesanggrahan Tamansari Yogyakarta (Yogyakarta: Depdikbud Direktorat Sejarah dan Nilai Tradisional Balai Penelitian Sejarah dan Budaya, 1981 - 1982), hlm. 24. 
Faktor yang mewujudkan terciptanya bentuk antara lain adalah fungsi, konstruksi, serta simbol. ${ }^{9}$ Sesuatu dirancang sedemikian rupa sehingga memberikan gambaran mengenai fungsinya. Dapat dikatakan bahwa fungsi adalah salah satu kriteria utama dalam perancangan bentuk. Bentuk dalam arsitektur adalah suatu unsur yang tertuju langsung pada mata, sehingga diharapkan dari bentuk tersebut dapat memberikan arti kepada si pemelihat secara visual. Sedangkan konstruksi dalam hal ini yang dimaksud adalah teknologi struktur serta bahan yang merupakan faktor penting dalam arsitektur. Sedangkan simbol adalah suatu perwujudan dari kebutuhan suatu identitas yang pada umumnya diinginkan oleh manusia.

Hubungan antara bentuk-fungsi-konstruksi serta simbol seperti di atas pada bangunan pesanggrahan-pesanggrahan Rejowinangun, Tamansari, serta Gua Siluman cukup jelas terlihat. Meskipun dalam hal ini tidak semua faktor seperti yang telah disebutkan, mempengaruhi dalam penciptaan bentuk. Dalam pembahasan ini akan dicoba melihat sejauh mana hubungan yang tercipta antara bentuk dengan faktor-faktor lain. Di sini fungsi merupakan variabel tetap sedangkan bentuk adalah variabel gayut.

\section{Fungsi pertahanan}

Telah disebutkan di depan bahwa salah satu bagian dari bangunan pesanggrahan-pesanggrahan mempunyai langit-langit lengkung. Secara teknis/konstruktif sistem lengkung (vaults) dapat diterapkan pada suatu bangunan yang bagian atasnya diperkirakan mempunyai gaya beban yang berlebihan. Beban ini merupakan gaya yang berarah ke bawah. Berdasarkan prinsipvektor gaya, beban akan didistribusikan ke kedua sisi lengkung. ${ }^{10}$ Dengan demikian beban tersebut tidak akan ditumpu pada

9. Hendraningsih, dkk., Peran, Kesan dan Pesan Bentuk-Bentuk Arsitektur (Jakarta: Jambatan, 1982), hlm. 10-11

10. Jero Wacik dan Suardhana Linggih. Ringkasan Fisika (Bandung: Ganeca Exact. 1985), hlm. Vektor 
satu bidang atau titik saja, sehingga kekuatan bangunan tidak banyak berkurang. Lain halnya jika langit-langit tersebut berbentuk datar, maka gaya beban akan mengumpul pada satu titik atau bidang saja. Untuk lebih jelasnya mengenai kedua sistem ini lihat gambar.

Dipakainya sistem lengkung pada langit-langit bangunan di bawah tanah berkaitan dengan fungsi bangunan tersebut, yaitu sebagai tempat pertahanan. Bangunan dengan langit-langit lengkung di bawah tanah didapatkan di Tamansari dan Gua Siluman. Di Tamansari untuk men. dukung fungsinya sebagai pertahanan, selain dilengkapi bangunan bawah tanah dilengkapi pula dengan sistem tata air. Dalam keadaan bahaya bagian-bagian pesanggrahan tertentu akan digenangi air sehing. ga seakan-akan genanganair yang ada.

Pada masa awal kesultanan Yogyakarta, bangunan seperti tersebut di atas memang dibutuhkan. Telah diketahui bahwa suasana politik pada masa itu dapat dikatakan tidak stabil. Pemberontakan dan peperangan dapat terjadi setiap saat. Keadaan yang demikian antara lain mendorong didirikannya tempat-tempat pertahanan, dalam hal ini pesanggrahan yang dirasa mempunyai banyak fungsi.

\section{Fungsi menyepi}

Fungsi pesanggrahan sebagai tempat untuk menyepi atau meditasi terwujud pada bangunan yang berlangit lengkung yang berada di permukaan tanah. Suasana yang diciptakan bangunan ini dapat disejajarkan dengan suasana gua. Keadaan gang demikian memberikan kesan sepi, gelap, dan dingin. Suasana semacam ini menunjang pencapaian konsentrasi yang dibutuhkan oleh seseorang yang sedang menjalani meditasi. Bangunan seperti ini didapatkan pada pesanggrahan Tamansari dan Rejowinangun. Pada kedua pesanggrahan tersebut bangunan ber langit lengkung dilengkapi dengan ceruk yang menyerupai mihrab masjid.

Bentuk lengkung pada ambang jendela dan pintu menimbulkan suatu kesan megah. Bentuk pintu dan jendela semacam ini merupakan lam. bang status bagi bangunan dan penghuninya. Kesan megah merupakan 
unsur mutlak bagi bangunan yang dimiliki oleh kelas penguasa, dalam hal ini Sultan Hamengku Buwana I maupun Sultan Hamengku Buwana II bahkan sultan-sultan sesudahnya. Bentuk lengkung pada jendela dan pintu pada mulanya dipakai untuk hal-hal yang berbau kemenangan. ${ }^{11}$ Misalnya pada ambang pintu gerbang yang dipakai untuk keluar dan masuknya pasukan. Melalui proses asosiasi dengan kejadian yang megah tersebut, akhirnya bentuk lengkung ini terpisah dengan fungsinya.

Bentuk lengkung suatu pintu atau jendela juga mengekspresikan keagungan bangunannya serta kegiatan yang ada di dalamnya. ${ }^{12}$ Bentuk lengkung seperti ini misalnya didapatkan pada gereja atau masjid.

\section{IV}

Berdasarkan uraian di depan dapat diketahui bahwa terdapat kaitan antara bentuk lengkung dengan fungsi pesanggrahan. Fungsi pesang grahan sebagai tempat pertahanan didukung oleh bangunan bawah tanah yang mempunyai langit-langit berbentuk lengkung. Secara teknis sistem lengkung (vaults) sesuai dipakai untuk langit-langit bangunan bawah tanah, karena gaya beban dapat didistribusikan ke bawah melalui lengkungan. Bangunan semacam ini terdapat di pesanggrahan Tamansari dan Gua Siluman. Selain itu, pesanggrahan Tamansari dan Rejowinangun dilengkapi bangunan untuk menyepi atau menghadap Yang Maha Kuasa yang berupa bangunan berlangit-langit lengkung dengan ceruk yang menyerupai mihrab. Bangunan ini merupakan bangunan di atas tanah. Dalam hal ini tidak tertutup kemungkinan bahwa bangunan yang berlangit-langit lengkung maupun bawah tanah juga mempunyai fungsi lain misalnya untuk menyepi. Kedua fungsi tersebut berkaitan dengan keadaan pemerintahan masa awal kesultanan Yogyakarta.

Untuk memberi kemegahan bangunan dan penghuninya dibuatlah bentuk-bentuk lengkung pada jendela dan pintu. Selain kemegahan yang

11. Hendraningsih, dkk., Op. cit., hlm. 47

12. lbid, hlm. 48. 
tercipta, bentuk lengkung juga melambangkan status bahwa penghuninya adalah kelas penguasa dalam hal ini Sultan pepundhen Ngayogyakarta. Bentuk-bentuk seperti ini digunakan hingga masa pemerintahan sultan-sultan sesudahnya.

\section{CATATAN}

1. Serat Rerenggan Kraton, Alih Aksara oleh Aryono (Jakarta: Proyek Penerbitan Buku Sastra Indonesia dan Daerah, 1981). hlm. 131.

2. Richard Etting Hausen, "The Man Made Setting". The World Of Islam (London: Thames and Hudson), hlm. 70-71.

3. Yang Hongxun, The Classical Gardens Of China (New York: Van Nostrand Reihold Company, 1982), hlm. 49.

4. Ibid. hlm. 13.

5. ibid. hlm. 85 .

6. S. Wojowasito, Kamus Kawi-Indonesia (Malang: - 1977) hlm. 236.

7. Denus Lombard, "Pandangan Orang Jawa Terhadap hutan". Citra Masyarakat Indonesia (Jakarta: Sinar Harapan. 1983). hlm. 246.

8. Tashadi (Ed). Mengenal Sekilar Bangunan Pesanggrahan Tamansari Yogyakarta (Yogyakarta: Depdikbud Direktorat Sejarah dan Nilai Tradisional Balai Penelitian Sejarah dan Budaya, 1981-1982). h!m. 24.

9. Hendraningsih. dkk.. Peran. Kesan dan Pesan Bentuk-Bentuk Arsitektur (Jakarta: Jambatan. 1982), hlm. 10-11.

10. Jero Wacik dan Suardhana Linggih, Ringkasan Fisika (Bandung: Ganeca Exact. 1985), hlm. Vektor.

11. Hendraningsih, dkk., Op. cit., hlm. 47.

12. Ibid, hlm. 48. 


\section{ACUAN}

Etting Hausen, Richard. 1982. "The Man Made Setting", The World of Islam. London: 'Thames and Hudson.

Hendraningsih, dkk. 1982. Peran, Kesan dan Pesan Bentuk-Bentuk Arsitektur. Jakarta: Jambatan.

Jero Wacik dan Suardhana Linggih. 1985. Ringkasan Fisika. Bandung: Ganeca Exact.

Lombard, Denys. 1983. "Pandangan Orang Jawa Terhadap Hutan", Citra Masyarakat Indonesia. Jakarta: Sinar Harapan.

Serat Rerenggan Kraton, Alih Aksara oleh Aryono. 1981. Jakarta: Proyek Penerbitan Buku Sastra Indonesia dan Daerah.

Wojowasito, S. 1977. Kamus Kawi-Indonesia. Malang:

Yang Hongxun. 1982. The Classical Gardens Of China. New York: Van Nostrand Reinhold Company.

Tashadi (Editor). 1981-1982. Mengenal Sekilas Bangunan

Pesanggrahan Tamansari Yogyakarta. Yogyakarta: Depdikbud

Direktorat Sejarah dan Nilai Tradisional Balai Penelitian Sejarah dan Budaya. 